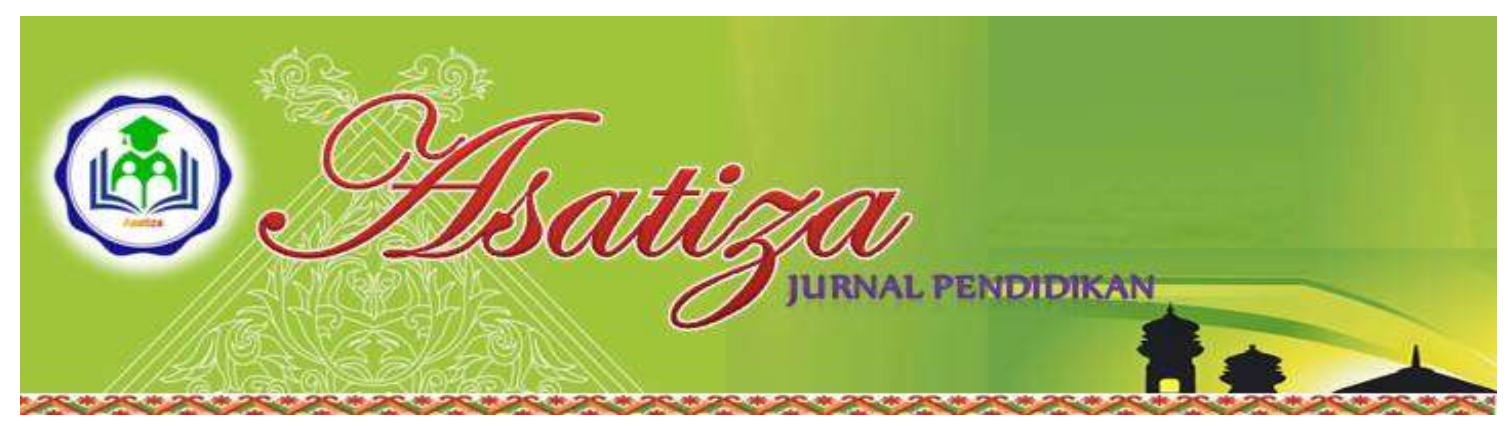

\title{
PELAKSANAAN PEMBELAJARAN KONSTRUTIVISTIK PADA MATA PELAJARAN PENDIDIKAN AGAMA ISLAM DI SEKOLAH DASAR NEGERI 011 PEKAN ARBA KECAMATAN TEMBILAHAN Asniah $^{1}$
}

${ }^{1}$ Mahasiswi Prodi PAI STAI Auliurrasyidin Tembilahan, Indonesia

\begin{abstract}
Abstrak
Permasalahan dalam penelitian ini dirumuskan sebagai berikut: Bagaimana pelaksanaan pembelajaran konstruktivistik pada mata pelajaran Pendidikan Agama Islam kelas tinggi di Sekolah Dasar Negeri 011 Pekan Arba Kecamatan Tembilahan? Apa faktor-faktor pendukung dalam pelaksanaan pembelajaran konstruktivistik pada mata pelajaran Pendidikan Agama Islam kelas tinggi di Sekolah Dasar Negeri 011 Pekan Arba Kecamatan Tembilahan?

Subjek dalam penelitian ini adalah guru mata pelajaran Pendidikan Agama Islam di Sekolah Dasar Negeri 011 Pekan Arba Kecamatan Tembilahan. Objek dalam penelitian ini adalah pelaksanaan pembelajaran konstruktivistik pada mata pelajaran Pendidikan Agama Islam di Sekolah Dasar Negeri 011 Pekan Arba Kecamatan Tembilahan.Populasi dalam penelitian ini adalah 3 orang guru mata pelajaran Pendidikan Agama Islam. Data dikumpulkan dengan menggunakan teknik observasi, wawancara, dan dokumentasi. Data dianalisa dengan menggunakan rumus persentase $\mathrm{P}=\mathrm{F} / \mathrm{N}$ x $100 \%$.

Dari hasil analisa data dapat disimpulkan bahwa Pelaksanaan pembelajaran konstruktivistik pada mata pelajaran Pendidikan Agama Islam di Sekolah Dasar Negeri 011 Pekan Arba Kecamatan Tembilahan, mencapai angka 59,03\% dan dikategorikan cukup baik, karena angka 59,03\% terletak pada interval 41\%-60\%. Adapun faktor-faktor yang mendukung adalah sebagai berikut: Guru telah melaksanakan pembelajaran sesuai dengan tujuan. Guru sudah menjelaskan tugas yang harus dilakukan siswa disertai contoh. Guru menyuruh siswa mengajukan dan menjawab pertanyaan. Guru bersama siswa menyimpulkan materi pelajaran. Guru telah melakukan evaluasi diakhir pembelajaran.
\end{abstract}

Kata Kunci: Pembelajaran, Kontrutivistik

\section{A. PENDAHULUAN}

\section{Latar belakang}

Paradigma pembelajaran yang dianut saat ini, dengan kata lain, mulai mengalami pergesaran dari penggunaan pendekatan behavioristik menjadi pendekatan konstuktivistik dalam penyelenggaraan aktivitas pembelajaran.
Pendekatan behavioristik merupakan pendekatan yang mapan karena telah lama digunakan. Saat ini, para pendidik mulai mencari pendekatan alternatif sebagai bentuk pendekatan lain dari pendekatan behavioristik.

Pendekatan teori belajar behavioristik menganggap bahwa perilaku yang 
dapat diukur dan diamati merupakan hasil belajar individu. Hal ini sangat berbeda dengan pandangan mengenai belajar berdasarkan pendekatan teori belajar konstruktivistik. Pendekatan ini menekankan pada perlunya proses mental seseorang dilibatkan secara aktif dalam menempuh proses belajar dan membangun pengetahuan. ${ }^{1}$

Para pengaut pendekatan konstruktivistik meyakini bahwa pengetahuan adalah sesuatu yang bersifat dinamis. Pengetahuan senantiasa mengalami perubahan dan perkembangan. Pengetahuan adalah proses yang memerlukan perkembangan. Pengetahuan adalah proses yang memerlukan tindakan. Belajar lebih diartikan sebagai sebuah proses konstruksi makna dari pada hanya sekedar mengingat dan menghafal fakta-fakta yang bersifat faktual. $^{2}$

Perubahan paradigma ini tidak dapat dihindari sekaligus juga mempengaruhi bidang desain sistem pembelajaran. Sejumlah buku desain sistem pembelajaran yang membahas model desain sistem pembelajaran telah memasukkan konsep pendekatan konstruktivistik di dalamnya.

Benny A. Pribadi mengemukakan definisi pendekatan konstruktivistik sebagai "pembelajaran yang menekankan pada peran aktif siswa dalam membangun pemahaman dan memberi makna terhadap informasi dan peristiwa yang dialami", 3

${ }^{1}$ Prawiladiga, Prinsip-Prinsip Pembelajaran, (Jakarta: Penerbit Kencana, 2002), h. 206.

${ }^{2}$ Ibid., h. 207.

${ }^{3}$ Benny A. Pribadi, Model Desain Sistem Pembelajaran, (Jakarta: Dian Rakyat, 2009), h. 156.
Hasil dari proses belajar merupakan kombinasi antara pengetahuan baru dengan pengetahuan atau pengalaman yang telah dimiliki sebelumnya. Individu dapat dikatakan telah menempuh proses belajar apabila ia telah membangun atau mengkonstruksi pengetahuan baru dengan cara melakukan penafsiran atau interpretasi baru terhadap lingkungan sosial, budaya, fisik, dan intelektual tempat mereka hidup.

Sedangkan kemandirian merupakan salah satu aspek kepribadian yang sangat penting bagi individu. Seseorang dalam menjalani kehidupan ini tidak pernah lepas dari cobaan dan tantangan. "Individu yang memiliki kemandirian tinggi relatif mampu menghadapi segala permasalahan karena individu yang mandiri tidak tergantung pada orang lain, selalu berusaha menghadapi dan memecahkan masalah yang ada". ${ }^{4}$

Menurut Antonius Gea, kemandirian juga dapat dikatakan;

"Kemampuan seseorang dalam mewujudkan sebuah kehendak atau keinginannya secara nyata dengan tidak bergantung pada orang lain. Dan jika dihubungkan dengan perilaku siswa dalam mewujudkan cita-citanya atau keinginannya untuk mencapai cita-cita secara nyata dengan tidak bergantung pada orang lain, dalam hal ini adalah siswa tersebut mampu melakukan belajar sendiri, dapat menentukan cara belajar yang efektif, mampu melaksanakan tugas-tugas belajar dengan baik dan mampu untuk

${ }^{4}$ Agus Dariyo, Psikologi Perkembangan Remaja, (Jakarta: Ghalia Indonesia, 2004), h. 24. 
melakukan aktivitas belajar secara mandiri. ${ }^{5}$

Akan tetapi melalui pengamatan pendahuluan yang dilakukan penulis dengan cara observasi di Sekolah Dasar Negeri 011 Pekan Arba Kecamatan Tembilahan, ditemukan kesenjangan dalam pelaksanaan pembelajaran konstruktivistik. Kesenjangan tersebut antara lain adalah guru telah melaksanakan model pembelajaran konstruktivistik, namun belum sesuai dengan langkah-langkahnya. Ada juga guru yang dalam melaksanakan proses pembelajaran masih mendominasi.

Padahal dalam pembelajaran kontruktivistik, justru siswalah yang dituntut untuk aktif. Pembelajaran kontruktivistik yang dilaksanakan guru belum dapat menunjang siswa untuk membangun suatu konsep berdasarkan pengalaman belajar. Siswa masih kesulitan dalam menyampaikan gagasan dan menghubungkan pengalaman seharihari dengan konsep, padahal ini merupakan bagian dalam pembelajaran kontruktivistik. Pembelajaran kontruktivistik yang dilaksanakan guru belum dapat menjadikan siswa memahami materi pelajaran secara lebih baik.

\section{Pengertian Konstruktivistik \\ Pembelajaran}

Pembelajaran kontrutivistik menuntut siswa untuk menemukan sendiri konsep pada suatu materi pembelajaran, melalui pengalaman belajar. Tentang pengertian pembelajaran ini Winkel (1991) dalam M. Sobry Sutikno menjelaskan bahwa pembelajaran;

${ }^{5}$ Antonius Gea, Relasi Dengan Diri Sendiri, (Jakarta: Gramedia, 2002), h. 145. "sebagai seperangkat tindakan yang dirancang untuk mendukung proses belajar peserta didik, dengan memperhitungkan kejadian-kejadian eksternal yang berperan terhadap rangkaian kejadian-kejadian internal yang berlangsung di dalam diri peserta didik". 6

Dimyati dan Mudjiono dalam buku yang sama mengartikan "pembelajaran sebagai kegiatan yang ditujukan untuk membelajarkan siswa". ${ }^{7}$ Dalam pengertian lain, "pembelajaran adalah usaha-usaha yang terencana dalam memanipulasi sumber-sumber belajar agar terjadi proses belajar dalam diri siswa". 8

Dari beberapa pengertian pembelajaran tersebut, dapat disimpulkan bahwa inti dari pembelajaran itu adalah segala upaya yang dilakukan oleh guru (pendidik) agar terjadi proses belajar pada diri siswa. Secara implisit, di dalam pembelajaran, ada kegiatan memilih, menetapkan dan mengembang kan metode untuk mencapai hasil pembelajaran yang diinginkan. Pembelajaran lebih menekankan pada cara-cara untuk mencapai tujuan dan berkaitan dengan bagaimana cara mengorganisasikan materi pelajaran, menyampaikan materi pelajaran, dan mengelola pembelajaran.

Sedangkan konstruktivistik menurut Anita Woolfolk dalam kutipan Benny A. Pribadi, mengemukakan definisi pendekatan konstruktivistik sebagai

\footnotetext{
${ }^{6}$ M. Sobry Sutikno, Belajar dan Pembelajaran; Upaya Kreatif dalam Mewujudkan Pembelajaran yang Berhasil, (Bandung: Prospect, 2009), h. 31.

${ }^{7}$ Ibid., h. 32.

${ }^{8}$ http://www.pendidikanmadrasah.blogspot. com/ 26 desember 2009. pukul 11.34 Wib.
} 
"pembelajaran yang menekankan pada peran aktif siswa dalam membangun pemahaman dan memberi makna terhadap informasi dan peristwa yang dialami". 9

Dalam hal ini Udin Syaefudin Sa'ud memberikan pendapat bahwa konstruktivistik adalah "proses membangun atau menyusun pengetahuan baru dalam struktur kognitif siswa berdasarkan pengalaman". ${ }^{10}$

Dengan demikian dapat disimpulkan bahwa pembelajaran konstruktivistik adalah merupakan salah satu pandangan tentang proses pembelajaran yang menyatakan bahwa dalam proses memperoleh pengetahuan diawali dengan terjadinya konflik kognitif, yang hanya dapat diatasi melalui pengetahuan diri. Pada akhir proses belajar, pengetahuan akan dibangun sendiri oleh anak didik melalui pengalamannya dari hasil interaktif dengan lingkungannya.

Menurut paradigma konstruktivistik, pembelajaran lebih mengutamakan pemecahan masalah, mengembangkan konsep, konstruksi solusi dan algoritma ketimbang menghafal prosedur dan menggunakannya untuk memperoleh satu jawaban benar. Pembelajaran lebih dicirikan oleh aktivitas eksperimentasi, pertanyaan-pertanyaan, investigasi, hipotesis, dan model-model yang dibangkitkan oleh pebelajar sendiri. Secara umum, terdapat lima prinsip dasar yang melandasi kelas konstruktivistik, yaitu:

${ }^{9}$ Benny A. Pribadi, Model Desain Sistem Pembelajaran, (Jakarta: Dian Rakyat, 2009), h.. 156.

${ }^{10}$ Udin Syaefudin Sa'ud, Inovasi Pendidikan, (Bandung: Alfabeta, 2009), h. 168. a. Meletakkan permasalahan yang relevan dengan kebutuhan pebelajar, yaitu masalah-masalah yang berhubungan dengan materi pelajaran, dan terdapat di sekitar kehidupan siswa. Hal ini dapat memudahkan siswa untuk memecahkan permasalahan dan menemukan kesimpulan.

b. Menyusun pembelajaran di sekitar konsep-konsep utama, yaitu dengan merancang pengalaman belajar yang menarik dan menjabarkan tuntutan kurikulum secara komprehensif.

c. Menghargai pandangan pebelajar. Hal ini diperlukan agar siswa dapat merasa nyaman dan senang mengikuti proses pembelajaran. Tugas guru dalam hal ini adalah mengarahkan siswa dan menjadi motivator agar siswa dapat memahami pembelajaran secara maksimal.

d. Materi pembelajaran menyesuaikan terhadap kebutuhan pebelajar. Maksudnya adalah pembelajaran dirancang sesuai dengan tingkat perkembangan siswa dan kebutuhan siswa.

e. Menilai pembelajaran secara kontekstual. Yaitu memberikan penilaian sesuai dengan kemampuan siswa. $^{11}$

Konstruksi pengetahuan merupakan proses berpikir dan menafsirkan tentang suatu peristiwa yang dialami. Setiap individu memiliki pengalaman unik. Oleh karenanya pengetahuan yang

${ }^{11}$ I Wayan Santyasa, Model Problem Solving dan Reasoning Sebagai Alternatif Pembelajaran Inovatif, (Surabaya: Perpect, 2004), h. 14. 
dimiliki oleh individu merupakan pengetahuan yang bersifat unik pula.

Proses belajar dalam diri individu dapat dikatakan telah terjadi apabila pengetahuan yang telah dimiliki dapat digunakan untuk menafsirkan pengalaman baru secara utuh, lengkap, dan lebih baik dari pada sebelumnya. Siswa perlu mengaitkan pengetahuan yang telah dimiliki sebelumnya dengan pengetahuan baru. Mengaitkan pengetahuan lama dengan pengetahuan baru merupakan hal yang prinsip untuk membangun ilmu pengetahuan.

\section{Komponen-Komponen Pembelajaran Konstruktivistik}

Tujuan pendekatan konstruktivistik dalam pembelajaran adalah agar siswa memiliki kemampuan dalam menemu kan, memahami, dan menggunakan informasi atau pengetahuan yang dipelajari. Implementasi pendekatan konstruktivistik dalam kegiatan pembelajaran perlu memperhatikan beberapa komponen penting sebagai berikut:

a. Belajar aktif (active learning).

b. Siswa terlibat dalam aktivitas pembelajaran yang bersifat otentik dan situasional.

c. Aktivitas belajar harus menarik dan menantang.

d. Siswa harus dapat mengaitkan informasi baru dengan informasi yang telah dimiliki sebelumnya dalam sebuah proses yang disebut "bridging".

e. Siswa harus mampu merefleksikan pengetahuan yang sedang dipelajari.

f. Guru harus lebih banyak berperan sebagai fasilitator yang dapat membantu siswa dalam melakukan konstruksi pengetahuan. Dalam hal ini, guru tidak lagi hanya sekedar berperan sebagai penyaji informasi.

g. Guru harus dapat memberi bantuan berupa scafolding yang diperlukan oleh siswa dalam menempuh proses belajar. $^{12}$

Agar kegiatan pembelajaran yang dilandasi oleh pendekatan konstruktivistik dapat memberikan hasil yang optimal, ada beberapa faktor yang perlu mendapat perhatian.

Dalam hal ini Hamzah memberikan pendapat sebagai berikut:

a. Memberi kesempatan kepada siswa untuk mengemukakan gagasannya dengan bahasa sendiri;

b. Memberi kesempatan kepada siswa untuk berfikir tentang pengalaman nya sehingga menjadi lebih kreatif dan imajinatif;

c. Memberi kesempatan kepada siswa untuk mencoba gagasan baru;

d. Memberi pengalaman yang berhubungan dengan gagasan yang telah dimiliki siswa;

e. Mendorong siswa untuk memikirkan perubahan gagasan mereka, dan;

f. Menciptakan lingkungan belajar yang kondusif. ${ }^{13}$

Dengan demikian, dapat disimpul kan bahwa pembelajaran yang mengacu kepada teori belajar konstruktivisme lebih menfokuskan pada kesuksesan siswa dalam mengorganisasikan pengalaman mereka. Bukan kepatuhan siswa dalam refleksi atas apa yang telah

\footnotetext{
${ }^{12}$ Benny A. Pribadi, Op. Cit., h. 161.

${ }^{13}$ Hamzah. Pembelajaran Matematika Menurut Teori Belajar Konstruktivisme. http://www.depdiknas.go.id/jurnal pendidikan dan kebudayaan.html. (17 Oktober 2006).
} 
diperintahkan dan dilakukan oleh guru.

Dengan kata lain, siswa lebih diutamakan untuk mengkonstruksi sendiri pengetahuan mereka melalui asimilasi dan akomodasi.

4. Langkah-Langkah Pembelajaran Konstruktivistik

Pembelajaran konstruktivistik dalam implementasinya melalui langkahlangkah yang terdiri dari komponen situasi, pengelompokkan, pengaitan, pertanyaan, eksibisi, dan refleksi. ${ }^{14}$

Secara rinci kutipan tersebut dijelaskan sebagai berikut:

a. Situasi. Komponen ini menggambar kan secara komprehensif tentang maksud atau tujuan dilaksanakannya aktivitas pembelajaran. Selain itu, dalam komponen situasi juga tergambar tugas-tugas yang perlu diselesaikan oleh siswa agar mereka memiliki makna dari pengalaman belajar yang telah dilalui.

b. Pengelompokan. Komponen pengelompokan dalam aktivitas pembelajaran berbasis pendekatan konstruktivis memberi kesempatan kepada siswa untuk melakukan interaksi dengan sejawat. Pengelompokan sangat bergantung pada situasi atau pengalaman belajar yang ingin dilalui oleh siswa. Pengelompokkan dapat dilakukan secara acak (random) atau didasarkan pada kriteria tertentu (porposive).

c. Pengaitan. Komponen pengaitan dilakukan untuk menghubungkan pengetahuan yang telah dimiliki oleh siswa dengan pengetahuan

${ }^{14}$ Benny A. Pribadi, Op. Cit., h. 163. yang baru. Bentuk-bentuk kegiatan pengaitan sangat bervariasi, misalnya melalui pemecahan masalah atau melalui diskusi topiktopik yang spesifik.

d. Pertanyaan. Pengajuan pertanyaan merupakan hal penting dalam aktivitas pembelajaran. Pertanyaan akan memunculkan gagasan asli yang merupakan inti dari pendekatan pembelajaran konstruktivistik. Dengan munculnya gagasan-gagasan yang bersifat orisinal, siswa dapat membangun pengetahuan d dalam dirinya.

e. Eksibisi. Komponen eksibisi dalam pembelajaran yang menggunakan pendekatan konstruktivistik memberi kesempatan kepada siswa untuk dapat menunjukkan hasil belajar setelah mengikuti suatu pengalaman belajar. Pengetahuan seperti apa yang telah dibangun oleh siswa setelah mengikuti proses pembelajar an dengan meng gunakan pendekat an konstruktivistik? Pertanyaan seperti ini perlu djawab untuk mengetahui hasil belajar siswa.

f. Refleksi. Komponen ini pada dasrnya memberi kesempatan kepada guru dan siswa untuk berpikir kritis tentang pengalaman belajar yang telah mereka tempuh baik personal maupun kolektif. Refleksi juga memberi kesempatan kepada siswa untuk berpikir tentang aplikasi dari pengetahuan yang telah mereka miliki.

Menurut Daud Tauhidi, langkahlangkah dalam pembelajaran konstruktivistik adalah sebagai berikut:

a. Visualisasi dan perencanaan tujuan; 
b. Skenario pengambilan keputusan;

c. Studi kasus;

d. Latihan-latihan;

e. Pemetaan informasi. ${ }^{15}$

Sedangkan menurut Ibrahim, dan kawan-kawan, pembelajaran konstruktivistik dilakukan melalui langkah-langkah sebagai berikut:

a. Menentukan topik

b. Menemukan masalah

c. Merumuskan konsep

d. Refleksi ${ }^{16}$

Dari beberapa teori di atas, dapat disimpulkan bahwa langkah-langkah dalam pembelajaran konstruktivistik adalah sebagai berikut:

a. Situasi

1) Guru menyampaikan tujuan pembelajaran.

2) Guru menjelaskan tugas-tugas yang harus dikerjakan siswa.

b. Pengelompokkan

1) Guru membentuk kelompok berdasarkan kedekatan tempat duduk

2) Guru memberikan kesempatan kepada siswa untuk berdiskusi.

3) Guru memberikan kesempatan kepada siswa untuk menceritakan pengalamannya.

4) Guru memberikan kesempatan kepada siswa untuk mengemuka kan gagasannya.

c. Pengaitan

1) Guru menyuruh siswa melakukan diskusi

${ }^{15}$ Daud Tauhidi, http://id.desainpembelajarankonstruktivistik.html.

${ }^{16}$ Ibrahim, dkk, Kurikulum dan Pembelajaran, (Jakarta: Raja Grafindo Persada, 2011), h. 208.
2) Guru membimbing siswa menghubungkan konsep dengan lingkungan melalui pemberian contoh.

3) Guru mengarahkan siswa menemukan masalah dalam kehidupan sehari-hari sesuai materi pelajaran.

d. Pertanyaan

1) Guru menyuruh siswa mengajukan pertanyaan.

2) Guru menyuruh siswa menjawab pertanyaan.

e. Eksibisi

1) Guru meminta siswa untuk menyampaikan hasil temuan nya.

2) Guru meminta siswa untuk menyimpulkan materi pelajar an.

f. Refleksi

1) Guru membimbing siswa menyimpulkan materi pelajar an.

2) Guru melakukan evaluasi.

3) Guru menggunakan hasil evaluasi untuk perbaikan pada pembelajar an berikutnya.

Pendekatan konstruktivistik dapat diaplikasikan pada semua jenjang dan satuan pendidikan. Hal penting yang perlu diperhatikan dalam menerapkan pendekatan konstruktivistik adalah memberi kebebasan kepada siswa untuk membangun pengetahuan dengan menggunakan beragam sumber belajar yang tersedia.

\section{B. METODOLOGI}

Subjek dalam penelitian ini adalah guru mata pelajaran Pendidikan Agama Islam di Sekolah Dasar Negeri 011 Pekan Arba Kecamatan Tembilahan.

Sedangkan objek dalam penelitian ini adalah pelaksanaan pembelajaran 
konstruktivistik pada mata pelajaran Pendidikan Agama Islam di Sekolah Dasar Negeri 011 Pekan Arba Kecamatan Tembilahan. Populasi dalam penelitian ini adalah: 3 orang guru PAI.

Data dalam penelitian ini dikumpulkan dengan menggunakan teknik observasi, wawancara dan dokumentasi,

Data yang sudah terkumpul, penulis kualifikasikan atau tuangkan ke dalam bentuk angka-angka. Sehingga data tersebut bersifat kuantitatif. Untuk selanjutnya dianalisa dan diinterpretasikan secara deskriptif. Untuk mendapatkan hasil persentase digunakan rumus:

$$
\mathrm{P}=\mathrm{X} 100 \% \frac{\mathrm{F}}{\mathrm{N}}
$$

Keterangan :

$\mathrm{P}=$ Angka Persentase

$\mathrm{F}=$ Frekuensi

$\mathrm{N}=$ Banyak Individu. ${ }^{17}$

\section{PEMBAHASAN}

Dalam penelitian ini observasi dilakukan kepada 3 (tiga) orang guru Pendidikan Agama Islam di Sekolah Dasar Negeri 011 Pekan Arba Kecamatan Tembilahan. Masing-masing guru tersebut diobservasi sebanyak 3 (tiga) kali.

Aspek-aspek yang diobservasi dicantumkan pada lembar observasi (terlampir). Peneliti melakukan observasi dengan cara mengamati langsung pada saat guru melaksanakan proses pembelajaran. Hasil observasi

${ }^{17}$ Anas Sudijono, Pengantar Statistik Pendidikan, (Jakarta: Raja Grafindo Persada, 2008), h. 43. tersebut disajikan secara sistematis di bawah ini.

Tabel IV.13

Rekapitulasi Hasil Observasi

Pelaksanaan Pembelajaran

Konstruktivistik Pada Mata Pelajaran

Pendidikan Agama Islam di Sekolah Dasar

Negeri 011 Pekan Arba Kecamatan Tembilahan

\begin{tabular}{|c|c|c|c|c|c|c|c|}
\hline \multirow{4}{*}{ No } & \multirow{4}{*}{$\begin{array}{l}\text { Aspek Yang } \\
\text { Diobservasi }\end{array}$} & \multicolumn{4}{|c|}{ Hasil Observasi } & \multirow{3}{*}{\multicolumn{2}{|c|}{ Jumlah }} \\
\hline & & \multirow{2}{*}{\multicolumn{2}{|c|}{\begin{tabular}{|c|} 
Dilaksar \\
akan
\end{tabular}}} & \multirow{2}{*}{\multicolumn{2}{|c|}{\begin{tabular}{|c|} 
Tidak \\
Dilaksar \\
akan
\end{tabular}}} & & \\
\hline & & & & & & & \\
\hline & & $\mathbf{F}$ & $\%$ & $\mathbf{F}$ & $\%$ & $\mathbf{F}$ & $\%$ \\
\hline 1 & $\begin{array}{l}\text { Guru } \\
\text { menyampaik } \\
\text { an tujuan } \\
\text { pembelajara } \\
\text { n }\end{array}$ & 8 & $\begin{array}{c}88,8 \\
9\end{array}$ & 1 & $\begin{array}{c}11,1 \\
1\end{array}$ & 9 & 100 \\
\hline 2 & $\begin{array}{l}\text { Guru } \\
\text { menjelaskan } \\
\text { tugas-tugas } \\
\text { yang harus } \\
\text { dikerjakan } \\
\text { siswa }\end{array}$ & 9 & 100 & 0 & 100 & 9 & 100 \\
\hline 3 & $\begin{array}{l}\text { Guru } \\
\text { memberikan } \\
\text { kesempatan } \\
\text { kepada } \\
\text { siswa untuk } \\
\text { berdiskusi } \\
\end{array}$ & 7 & $\begin{array}{c}77,7 \\
8\end{array}$ & 2 & $\begin{array}{c}22,2 \\
2\end{array}$ & 9 & 100 \\
\hline 4 & $\begin{array}{l}\text { Guru } \\
\text { memberikan } \\
\text { kesempatan } \\
\text { kepada } \\
\text { siswa untuk } \\
\text { menceritaka } \\
\text { n } \\
\text { pengalaman } \\
\text { nya }\end{array}$ & 6 & $\begin{array}{c}66,6 \\
7\end{array}$ & 3 & $\begin{array}{c}33,3 \\
3\end{array}$ & 9 & 100 \\
\hline 5 & $\begin{array}{l}\text { Guru } \\
\text { memberikan } \\
\text { kesempatan } \\
\text { kepada } \\
\text { siswa untuk } \\
\text { mengemuka } \\
\text { kan } \\
\text { gagasannya }\end{array}$ & 6 & $\begin{array}{c}66,6 \\
7\end{array}$ & 3 & $\begin{array}{c}33,3 \\
3\end{array}$ & 9 & 100 \\
\hline 6 & $\begin{array}{l}\text { Guru } \\
\text { menyuruh } \\
\text { siswa } \\
\text { melakukan } \\
\text { diskusi }\end{array}$ & 1 & $\begin{array}{c}11,1 \\
1\end{array}$ & 8 & $\begin{array}{c}88,8 \\
9\end{array}$ & 9 & 100 \\
\hline 7 & $\begin{array}{l}\text { Guru } \\
\text { membimbin } \\
\text { g siswa } \\
\text { menghubung }\end{array}$ & 9 & 100 & 0 & 100 & 9 & 100 \\
\hline
\end{tabular}




\begin{tabular}{|c|c|c|c|c|c|c|c|}
\hline & $\begin{array}{l}\text { kan konsep } \\
\text { dengan } \\
\text { lingkungan } \\
\text { melalui } \\
\text { pemberian } \\
\text { contoh }\end{array}$ & & & & & & \\
\hline 8 & $\begin{array}{l}\text { Guru } \\
\text { mengarahka } \\
\mathrm{n} \text { siswa } \\
\text { menemukan } \\
\text { masalah } \\
\text { dalam } \\
\text { kehidupan } \\
\text { sehari-hari } \\
\text { sesuai materi } \\
\text { pelajaran }\end{array}$ & 5 & $\begin{array}{c}55,5 \\
6\end{array}$ & 4 & $\begin{array}{c}44,4 \\
4\end{array}$ & 9 & 100 \\
\hline 9 & $\begin{array}{l}\text { Guru } \\
\text { menyuruh } \\
\text { siswa } \\
\text { mengajukan } \\
\text { pertanyaan }\end{array}$ & 2 & $\begin{array}{c}22,2 \\
2\end{array}$ & 7 & $\begin{array}{c}77,7 \\
8\end{array}$ & 9 & 100 \\
\hline 10 & $\begin{array}{l}\text { Guru } \\
\text { menyuruh } \\
\text { siswa } \\
\text { menjawab } \\
\text { pertanyaan } \\
\end{array}$ & 7 & $\begin{array}{c}77,7 \\
8\end{array}$ & 2 & $\begin{array}{c}22,2 \\
2\end{array}$ & 9 & 100 \\
\hline 11 & $\begin{array}{l}\text { Guru } \\
\text { menyuruh } \\
\text { siswa } \\
\text { menyampaik } \\
\text { an hasil } \\
\text { temuannya }\end{array}$ & 7 & $\begin{array}{c}77,7 \\
8\end{array}$ & 2 & $\begin{array}{c}22,2 \\
2\end{array}$ & 9 & 100 \\
\hline 12 & $\begin{array}{l}\text { Guru } \\
\text { meminta } \\
\text { siswa } \\
\text { menyimpulk } \\
\text { an materi } \\
\text { pembelajara } \\
\text { n }\end{array}$ & 2 & $\begin{array}{c}22,2 \\
2\end{array}$ & 7 & $\begin{array}{c}77,7 \\
8\end{array}$ & 9 & 100 \\
\hline 13 & $\begin{array}{l}\text { Guru } \\
\text { membimbin } \\
\text { g siswa } \\
\text { menyimpulk } \\
\text { an materi } \\
\text { pelajaran }\end{array}$ & 4 & $\begin{array}{c}44,4 \\
4\end{array}$ & 5 & $\begin{array}{c}55,5 \\
6\end{array}$ & 9 & 100 \\
\hline 14 & $\begin{array}{l}\text { Guru } \\
\text { melakukan } \\
\text { evaluasi }\end{array}$ & 2 & $\begin{array}{c}22,2 \\
2\end{array}$ & 7 & $\begin{array}{c}77,7 \\
8\end{array}$ & 9 & 100 \\
\hline 15 & $\begin{array}{l}\text { Guru } \\
\text { menyampaik } \\
\text { an tujuan } \\
\text { pembelajara } \\
\text { n }\end{array}$ & 6 & $\begin{array}{c}66,6 \\
7\end{array}$ & 3 & $\begin{array}{c}33,3 \\
3\end{array}$ & 9 & 100 \\
\hline 16 & $\begin{array}{l}\text { Guru } \\
\text { menjelaskan } \\
\text { tugas-tugas } \\
\text { yang harus }\end{array}$ & 4 & $\begin{array}{c}44,4 \\
4\end{array}$ & 5 & $\begin{array}{c}55,5 \\
6\end{array}$ & 9 & 100 \\
\hline
\end{tabular}

\begin{tabular}{|l|l|l|l|l|l|l|}
\hline $\begin{array}{l}\text { dikerjakan } \\
\text { siswa }\end{array}$ & & & & & & \\
\hline Jumlah & $\mathbf{8 5}$ & $\mathbf{5 9 ,}$ & $\mathbf{5}$ & $\mathbf{4 0 ,}$ & $\mathbf{1 4}$ & $\mathbf{1 0 0}$ \\
$\mathbf{0 3}$ & $\mathbf{9}$ & $\mathbf{9 7}$ & $\mathbf{4}$ & \\
\hline
\end{tabular}

Dari tabel di atas diketahui bahwa hasil observasi secara keseluruhan adalah 85 kali dilaksanakan $(59,03 \%)$ dan 59 kali tidak dilaksanakan (40,97\%). Selanjutnya hasil observasi dilaksanakan diberi skor 1 dan hasil observasi tidak dilaksanakan diberi skor $0 .^{18}$

Maka didapat hasil:

Dilaksanakan $=85 \times 1=85$

Tidak Dilaksanakan $=59 \times 0=0$

Jumlah Total $=85$

Maka, $\mathrm{F}=85$, dan

$\mathrm{N}=$ Jumlah Populasi $\mathrm{x}$ Jumlah Aspek yang Diobservasi $\mathrm{x}$ Jumlah Observasi x Skor Tertinggi

$$
\begin{aligned}
& =\quad 3 \times 16 \times 3 \times 1 \\
& =\quad 144
\end{aligned}
$$

Untuk mengetahui pelaksanaan pembelajaran konstruktivistik pada mata pelajaran Pendidikan Agama Islam di Sekolah Dasar Negeri 011 Pekan Arba Kecamatan Tembilahan, digunakan rumus:

$$
\begin{aligned}
\mathrm{P} & =\frac{\mathrm{F}}{\mathrm{N}} \mathrm{X} 100 \% \\
\mathrm{P} & =\frac{85}{\mathrm{X}} \mathrm{X} 100 \% \\
& =59,03 \%
\end{aligned}
$$

Dengan demikian, pelaksanaan pembelajaran konstruktivistik pada mata pelajaran Pendidikan Agama Islam di Sekolah Dasar Negeri 011 Pekan Arba Kecamatan Tembilahan, mencapai angka $59,03 \%$ dan dikategorikan cukup baik,

${ }^{18}$ Riduwan, Belajar Mudah Penelitian Untuk uru, Karyawan, Peneliti Pemula, (Bandung: Alfabeta, 2004), h. 91. 
karena angka $59,03 \%$ terletak pada interval $41 \%-60 \%$.

Dari sejumlah wawancara yang telah dilakukan penulis, dapat dilakukan pembahasan sebagai berikut:

Secara umum guru Pendidikan Agama Islam tidak menyampaikan tujuan pembelajaran secara langsung, namun tetap menyampaikan pembelajar an sesuai dengan tujuan. Cara guru menjelaskan tugas-tugas yang harus dikerjakan siswa cukup bervariasi, ada yang disertai contoh, ada juga yang hanya dijekaskan namun siswa sudah dapat mengerti.

Kesempatan untuk melakukan diskusi hanya sesekali saja diberikan oleh guru Pendidikan Agama Islam, karena harus menyelesaikan dengan materi pembelajaran yang disampaikan. Demikian pula dalam hal menceritakan pengalaman dan kesempatan mengemukakan pendapat, serta melakukan diskusi. Semua ini hanya dilakukan sesuai dengan tuntutan materi pelajaran.

Sedangkan cara yang ditempuh untuk mengarahkan siswa dalam menghubungkan konsep dengan lingkungan melalui contoh, sering dilakukan guru agar pengalaman belajar yang didapat siswa dapat lebih berkesan. Untuk mengarahkan siswa menemukan masalah dalam kehidupan sehari-hari, guru selalu menggali pengalaman siswa melalui pertanyaan-pertanyaan. Agar pembelajaran lebih maksimal, guru juga selalu menyuruh siswa mengajukan pertanyaan dan menjawab pertanyaan sesuai dengan materi pelajaran yang disampaikan. Sedangkan menyuruh siswa menyampaikan hasil temuan, tidak pernah dilakukan.

Setiap proses pembelajaran, selalu diakhiri dengan membuat kesimpulan dan evaluasi. Kesimpulan diberikan dengan cara mengulang inti dari materi pembelajaran yang disampaikan, dan evaluasi dilakukan secara lisan dan tulisan.

\section{KESIMPULAN}

Dari hasil analisa data dapat disimpulkan sebagai berikut:

1. Pelaksanaan pembelajaran konstruktivistik pada mata pelajaran Pendidikan Agama Islam di Sekolah Dasar Negeri 011 Pekan Arba Kecamatan Tembilahan, mencapai angka 59,03\% dan dikategorikan cukup baik, karena angka 59,03\% terletak pada interval $41 \%-60 \%$.

2. Adapun faktor-faktor yang mendukung adalah sebagai berikut:

a. Guru telah melaksanakan pembelajaran sesuai dengan tujuan.

b. Guru sudah menjelaskan tugas yang harus dilakukan siswa disertai contoh.

c. Guru menyuruh siswa mengajukan dan menjawab pertanyaan.

d. Guru bersama siswa menyimpul kan materi pelajaran.

e. Guru telah melakukan evaluasi diakhir pembelajaran.

\section{REFERENSI}

Abdullah. (2001). Kemandirian Dalam Belajar. Bandung: Prospect.

Abu Ahmadi dan Widodo Supriyono. 2004. Psikologi Belajar. Jakarta: Rineka Cipta. 
Agus Dariyo. (2004). Psikologi Perkembangan Remaja. Jakarta: Ghalia Indonesia.

Anas Sudijono. (2009). Pengantar Evaluasi Pendidikan. Jakarta: Raja Grafindo Persada.

Antonius Gea. (2002). Relasi Dengan Diri Sendiri. Jakarta: Gramedia.

Benny A. Pribadi (2009). Model Desain Sistem Pembelajaran. Jakarta: Dian Rakyat.

Burhan Bungin. (2010). Metodologi Penelitian Kuantitatif. Jakarta: Prenada Media Group.

Chabib Thoha. (2006). Kapita Selekta Pendidikan Islam. Yogyakarta: Pustaka Pelajar.

Cholid Narbuko dan Abu Ahmadi. (2005). Metodologi Penelitian Pendidikan. Jakarta: Bumi Aksara.

Danang Kahmad. (2000). Metodologi Penelitian Agama. Bandung: Pustaka Setia.

Daryanto. (2010). Belajar dan Mengajar. Bandung: Yrama Widya.

Haris Mujiman. (2005). Belajar Mandiri. Bandung: Rosdakarya.

Hasan Basri. (2000). Remaja Berkualitas; Problematika Remaja dan Solusinya. Yogyakarta: Pustaka Pelajar.

Hendra Surya. (2003). Kiat Mengajak Anak Belajar dan Berprestasi. Jakarta: Gramedia.

Ibrahim, dkk. (2011). Kurikulum dan Pembelajaran. Jakarta: Raja Grafindo Persada.

I Wayan Santyasa. (2004). Model Problem Solving dan Reasoning Sebagai Alternatif Pembelajaran Inovatif. Surabaya: Perpect.

Iskandar. (2010). Metodologi Penelitian Pendidikan. Jakarta: Gaung Persada Press.

M. Sobry Sutikno. (2009). Belajar dan Pembelajaran; Upaya Kreatif dalam Mewujudkan Pembelajaran yang Berhasil. Bandung: Prspect.
Muhibbin Syah. (2002). Psikologi Pendidikan dengan Pendekatan Baru. Bandung: Rosdakarya.

Prawiladiga. (2002). Prinsip-Prinsip Pembelajaran. (Jakarta: Penerbit Kencana.

Riduwan. (2004). Metode dan Teknik Menyusun Tesis. Bandung: Alfabeta. - (2002). Skala Pengukuran Variabel-Variabel Penelitian. Bandung: Alfabeta.

Singgih D. Gunarsa. (2004). Psikologi Perkembangan. Jakarta: Pustaka Setia.

Slameto. (2003). Belajar dan FaktorFaktor yang Mempengaruhinya. Jakarta: Rineka Cipta.

Sofan Amri. (2013). Pengembangan dan Model Pembelajaran dalam Kurikulum 2013. Jakarta: Prestasi Pustakaraya.

Suharsimi Arikunto. 2006. Prosedur Penelitian Suatu Pendekatan Praktik. Jakarta: Rineka Cipta.

Sukardi. (2005). Metodologi Penelitian Pendidikan. Jakarta: Bumi Aksara.

Tim Reality. (2008). Kamus Terbaru Bahasa Indonesia. Surabaya: Reality Publisher.

Udin Syaefudin Sa'ud. (2009). Inovasi Pendidikan. Bandung: Alfabeta.

Hamzah. Pembelajaran Matematika Menurut Teori Belajar Konstruktivisme. 